\section{SIMBOLISME MENURUT MIRCEA ELIADE}

Ivan Th. I. Weismann, S.Th., M.Hum.

\section{Pengertian Simbol secara Etimologi}

Kata "simbol" berasal dari kata Yunani sumballeo, sumballein atau sumball es thaiyang berartiberunding, berdebat, merenungkan, bertemu, membantu (Sutanto, 2003: 727), berwawancara, melemparkan menjadi satu, menyusun atau menyatukan, menetapkan, menggabungkan, menyetujui, membandingkan, menjelaskan, menafsir, mengapresiasi (Thayer, 1981: 595). Simbol juga berarti penyatuan dua hal luluh menjadi satu (Dibyasuharda, 1990: 11). Kata ini berasal dari suatu kegiatan praktis pada masa lampau berupa sebuah cincin, koin, atau lempengan tanah liat yang dibagi dua, untuk mengadakan perjanjian antara dua pihak. Yang separuh berarti pelengkap dari separuh yang lainnya; atau berarti keseluruhan ketika separuh yang lain tidak ada. Kegiatan praktis dalam bentuk potongan suatu bagian dengan maksud untuk perbandingan dan kecocokan pasangan adalah awal keberadaan simbol. Potongan-potongan dari suatu unit yang dibagi, keduanya disebut simbol (Savickas, 1980: 2-3).

\section{Pengertian Simbol secara Umum}

Beberapa pendapat dari para pakar tentang arti simbol secara umum dalam penulisan ini, penulis kutip dari karya John A. Saliba yang berjudul 'Homo Religiosus' in Mircea Eliade. Kajian simbolisme sering disertai dengan membedakan antara simbol dan tanda. Perbedaan tanda dan simbol menurut Saliba ialah bahwa tanda secara umum memberikan informasi tentang suatu keadaan dari kejadian, hal, atau hubungan, seperti: lampu lalu lintas memberikan informasi khusus. Simbol adalah sarana atau pembawa buah pikiran atau makna. Simbol mengandung suatu pengertian yang tidak mengandung informasi langsung (Saliba, 1976:83).

Menurut Edwin Smith, simbol yang diartikan dalam hubungan dengan sesuatu yang lain disebut objek atau referensi (acuan, rujukan, atau pola dasar penafsiran yang ditetapkan terlebih dahulu). Simbol berupa referensi atau objek itu menggambarkan makna referensi, atau sarana untuk memahami suatu referensi atau objek, suatu bagian yang mewakili keseluruhan, atau yang berfungsi untuk mengingat kembali suatu referensi atau objek yang hilang (Saliba, 1976: 83).

John A. Saliba menambahkan pula bahwa simbol tidak memberi arti langsung kepada benda, objek, atau referensi, tetapi terhadap ideal-ideal, nilai-nilai dan paham-paham abstrak. Simbolisme adalah suatu bentuk komunikasi yang ekspresif, mengandung suatu pesan atau informasi yang tidak dapat dikatakan secara langsung (Saliba, 1976: 83). Selain itu, simbol tidak dapat memberi arti langsung oleh karena menurut John H. M. Beattie, simbol berimplikasi makna yang tidak berasal dari konteks pengalaman, karena simbol merujuk pada realitas yang lain atau di luar konteks pengalaman (Saliba, 1976: 83).

Adapun fungsi simbol adalah fungsi bahasa. Fungsi simbol ini dijelaskan J. A. Hostetler yaitu sebagai saluran (channel) untuk segala kepercayaan dan sikap lalui dari suatu generasi ke generasi berikutnya. Simbol juga adalah saluran bagi emosi manusia. Simbol bukan saja hasil dari prosedur pemikiran, tetapi simbol juga adalah hasil dari suatu proses historis. Sebagai contoh: pakaian jilbab, adalah mekanisme yang efektif untuk mempertahankan kesadaran kelompok dan mengintegrasikan nilai-nilai kelompok masyarakat 
atau khususnya kaum wanita Muslim. Fungsi simbol dalam hal ini cenderung memperkuat budaya dan memelihara identitas (Saliba, 1976: 83).

Fungsi simbol yang lain lagi dikemukakan oleh Godfrey Lienhardt yaitu suatu maksud untuk mendapatkan pengaruh yang diinginkan. Simbol tidak saja mengusulkan perubahan atas status moral dan sosial tetapi juga membawa perubahan tersebut atas suatu masyarakat. Umumnya simbol yang demikian itu seringkali identik dengan referensinya, sehingga masyarakat berperilaku terhadap simbol seperti terhadap yang disimbolisasikan. Contohnya ritual berburu, dimaksudkan untuk suatu tujuan yang diinginkan, yaitu mendapatkan makanan dengan bantuan dewa-dewa atau roh-roh. Namun, ritus ini disertai pula dengan tindakan aktual berburu yang dilengkapi dengan berbagai persenjataan. Menurut Lienhardt, simbol tersebut tidak saja membawa hasil yang diinginkan, tetapi tindakan simbol itu juga berfungsi sebagai pelengkap dan persiapan untuk tindakan praktis atau teknis (Saliba, 1976: 84).

Fungsi simbol menurut Victor $W$. Turner tidak dalam alam sadar melainkan di bawah alam sadar, namun tidak berarti simbol tidak masuk akal atau tanpa logika. Simbol berjalan menurut aturan-aturan dan sangat terstruktur. Simbol melibatkan mekanisme proyeksi alam bawah sadar, tetapi juga sebagian diatur oleh pemikiran konseptual alam sadar. Analisa struktur mitos dan ritual didasarkan pada logika terhadap representasi simbolik dan berusaha menimbulkan makna dari ritual dan kepercayaan religius itu melalui suatu analisa kerangka simbol. Pendekatan ini menekankan bahwa simbol sering membentuk suatu pola yang terstruktur, yaitu bahwa makna suatu simbol tertentu berhubungan dengan simbol lain yang terdapat dalam suatu kelompok simbol itu sendiri. Makna simbol dapat dicapai se- penuhnya jika dilihat sebagai bagian dari suatu sistem kompleks dari ide-ide yang saling berhubungan. Oleh karena itu menurut Turner, simbol dapat menjadi multivalent, yaitu menyatakan motivasi yang berbeda. Simbol dapat juga menjadi multivokal, yaitu memiliki ideologi dan kognitif yang berbeda. Suatu simbol dapat memiliki banyak makna pada saat yang sama. Namun simbol-simbol yang berbeda dapat pula mengandung suatu ide umum atau mengandung pola simbolik yang sama yang terdapat dalam situasi-situasi ritual yang berbeda. Simbol-simbol yang dominan dalam konteks ritual, adalah kunci utama dalam menafsirkan motivasi, ideology, dan kognitif suatu masyarakat (Saliba, 1976: 84-85).

Menurut Turner, kajian simbolisme terdiri dari tiga level. Pertama adalah level etnografis. Level ini menggambarkan bentuk eksternal dan karakteristik yang dapat diamati dari situasi simbolik. Yaitu mencatat tentang objek, tempat, perkataan dan tindakan dari representasi simbolik. Level ini tidak menghasilkan makna dari simbol yang digunakan. Yang penting dalam simbolisme bukan objeknya tetapi ide-ide di belakangnya. Hal ini memimpin kepada level eksegesis. Level ini menanyakan apa yang masyarakat katakan tentang simbol mereka sendiri. Level ini menekankan simbolisme dalam alam sadar. Informasi level ini diperoleh dari ahli agama dan dari kaum awam. Mitos dapat menjadi suatu eksegesis dari ritual simbolik tertentu, karena budaya umumnya berasal dari eksegesis literatur lisan dan tertulis dari suatu masyarakat. Level ketiga ialah level eksplanasi, yaitu yang bersifat menjelaskan. Level ini adalah analisa kontekstual. Menurut E. E. Evans-Pitchard, simbol seringkali mengandung seperangkat yang rumit mengenai hubungan sosial dan berimplikasi moral, sehingga simbolisme seringkali sulit dimengerti secara eksplisit. Akan tetapi, 
petunjuk-petunjuk untuk memahami simbol terdapat dalam kehidupan seharihari. Menurut Mary Douglas, ide-ide masyarakat tentang kepemilikan, ideal-ideal mereka tentang kemanusiaan, dan konsep mereka tentang kesucian sering menjadi rujukan atas penafsiran ritus simbolik mereka. Monica Wilson juga menambahkan bahwa gambar-gambar yang digunakan manusia, objek-objek yang mewakili nilai-nilai dan konsep religius suatu masyarakat sering ditentukan oleh lingkungan fisik dan budaya. Oleh karena itu, segala kesulitan untuk memahami simbol dapat diatasi melalui analisa kontekstual atau level eksplanasi yaitu dengan mengenal lingkungan fisik dan budaya suatu masyarakat. Simbol tidak dapat dikaji terpisah dari budaya, yaitu kehidupan sosial, paham-paham dan nilai-nilai religius (Saliba, 1976: 86-87).

\section{Simbol pada Mircea Eliade}

\section{Riwayat Hidup}

Dibyasuharda dalam disertasinya yang berjudul Dimensi Metafisik dalam Simbol memaparkan secara ringkas riwayat hidup Mircea Eliade. Mircea Eliade lahir di Bukarest, Rumania pada tahun 1907. Mula-mula ia belajar filsafat, dan sebagai filsuf pada tahun 1928, ia pergi ke India untuk belajar di bawah bimbingan Dasgupta di Universitas Calcutta. Ia tinggal empat tahun di India, termasuk enam bulan di biara Rishikesh di daerah Himalaya, untuk mempelajari teori dan praktek Yoga. Eliade meraih pengakuan keahlian dalam bidang filsafat dengan disertasi tentang yoga pada tahun 1933, dan sejak itu ia bekerja di Universitas Bukarest. Dalam masa perang dunia kedua ia memangku jabatan diplomatik di Lisabon dan London.

Pada tahun 1945 Eliade menjadi dosen tamu di Sorbone dan sejak 1957 ia diangkat sebagai mahaguru pada Uni- versitas Chicago dalam mimbar sejarah agama-agama. Eliade begitu tertarik oleh kehidupan dan pemikiran arkais dan mencoba memberikan interpretasi intelektual dalam konteks tradisi intelektual Barat. Karya-karya tulis Eliade membuat dia terkenal sebagai pakar dalam bidang sejarah agama-agama dan dalam fenomenologi agama (Dibyasuharda, 1990: 159-160).

\section{Pemikiran Eliade tentang Simbol}

Karya John A. Saliba yang berjudul 'Homo Religiosus' in Mircea Eliade, halaman 54-57, sekali lagi penulis gunakan sebagai bahan rujukan dalam tulisan ini untuk menjelaskan pemikiran Eliade tentang simbol. Eliade mengakui bahwa semua kegiatan manusia melibatkan simbolisme, bahkan simbol adalah cara khusus untuk mengenal hal-hal religius. Oleh karena manusia adalah makhluk fana dan penuh keterbatasan oleh hal duniawi, maka manusia tidak dapat memiliki akses ke hal yang sakral, dan yang transenden. Pengetahuan manusia atas yang sakral bukan sepenuhnya hasil dari usaha manusia itu sendiri, atau produk dari akal rasionalitasnya. Manusia mengetahui hal yang sakral oleh karena yang sakral itu menyatakan dirinya kepada manusia melalui wahyu seperti hierophani (penyataan diri yang kudus), atau kratophani (penyataan diri yang maha kuasa). Cara inilah yang disebut dengan simbol agar yang sakral itu dapat menyatakan dirinya kepada manusia, dan dengan simbol itu manusia dapat mencapai pengetahuan tentang yang sakral dan transenden. Sebagai contoh, langit adalah simbol tentang yang sakral untuk menyatakan dirnya kepada manusia. Menurut Eliade, transendensi Allah dinyatakan secara langsung dalam sifat-sifat langit yang memiliki sifat ketidakterbatasan, kekekalan, keadaan yang tidak dapat didekati atau ditaklukkan, dan kekuatan kreatif (hujan). 
Simbol adalah cara ekspresi yang lebih berkualitas dibandingkan perkataan manusia. Simbol mampu menampung informasi yang sulit bahkan yang tidak mungkin untuk diekspresikan. Simbol adalah tanda-tanda realitas transenden, memberikan pandangan yang jelas mengenai keberadaan yang sakral itu. Simbol disebut bentuk wahyu yang otonom. Simbol memiliki keunikan karena memberikan pemahaman yang jelas mengenai yang sakral dan realitas kosmologis yang tidak ada manifestasi lain mampu menyatakannya. Simbol memainkan peran penting dalam kehidupan religius manusia dan membawa manusia kepada makna yang lebih dalam dari pengetahuan biasa atau sehari-hari.

Eliade tidak mempertentangkan antara pemikiran simbolik dengan pemikiran rasional atau konseptual. Eliade hanya membedakan antara simbol dan konsep. Eliade menegaskan bahwa manusia bukan saja makhluk "rasional" tetapi juga "homo simbolikus". Pemikiran simbolik adalah suatu sistem yang koheren atau saling berhubungan. Setiap simbol memiliki unsur metafisika dan logika. Konsep metafisika tidak selalu dirumuskan dalam bahasa teoritis; tetapi simbol, ritual, dan mitos dapat pula menjelaskan tentang realitas yang mendasar tentang segala sesuatu, dan juga sebagai suatu sistem yang diterima sebagai suatu metafisika. Eliade juga menyinggung struktur logika tentang simbolisme, bahwa simbol dapat dirumuskan secara sistematis, dan diterjemahkan dalam istilahistilah yang rasional. Adapun perbedaan antara konsep dan simbol; konsep adalah tindakan khusus dari intelegensi manusia atau kemampuan akalnya, sedangkan simbol adalah tindakan dari keseluruhan manusia. Simbol membicarakan keseluruhan manusia dan bukan hanya intelegensinya. Simbol terdapat dalam hal-hal religius karena semua fenomena religius melibatkan totalitas manusia, dan bukannya hanya usaha intelek dan imajinasi. Ketika rasionalisasi dan sistematisasi menjadi dominan dalam pemikiran konseptual maka ini menunjukkan minimnya pemikiran simbolik dalam diri seseorang. Sedangkan emosi dan intusi yang dominan adalah bukti pemikiran simbolik yang maksimal. Ketika alam sadar berperan penting dalam rasionalisasi dan konseptualisasi, maka alam bawah sadar berperan penting dalam proses simbolisasi. Simbol tidak saja terdapat dalam alam sadar tetapi juga dalam totalitas kehidupan psikis atau kejiwaan. Selain itu, simbol berbeda dengan konsep karena simbol menekankan sifat sosial manusia. Mitos sebagai salah satu bentuk dari simbol menjadikan simbol mitos itu milik suatu masyarakat, begitu pula dengan ritual sebagai suatu bentuk simbol membuat manusia menjalankan tindakan ritual itu sebagai suatu kelompok. Simbolisme membuat manusia tidak merasa dirinya terisolasi dari dunia. Sedangkan konseptualisasi menekankan individualitas manusia, suatu tindakan yang dikerjakan manusia seorang diri.

Eliade juga menekankan nilai eksistensial simbolisme. Simbol selalu mengarahkan pada suatu realitas atau suatu situasi di mana eksistensi manusia terlibat di dalamnya. Simbol senantiasa menjaga hubungan dengan sumber kehidupan yang terdalam; simbol juga menyatakan kehidupan rohani. Sayangnya simbol bernasib malang, sama dengan mitos. Kehidupan manusia modern mulai mengabaikan mitos, mendesakralisasikan dan mensekularisasikan simbol. Simbol telah terperosok ke dalam suatu keadaan yang disebut takhayul. Simbol telah kehilangan makna religiusnya dan yang tersisa hanya nilai sosial dan artistiknya. Simbol menjadi lebih dirasionalisasikan, didesakralisasikan, dan dipandang sebagai kekanak-kanakan. Akibat perlaku- 
an manusia modern atas simbol yang demikian itu membuat manusia itu hidup dalam lingkungan yang diciptakannya sendiri yang di dalamnya ada jurang yang dalam antara dirinya dengan yang kudus. Hanya simbol yang dapat mengintegrasikan manusia dengan yang kudus, dan melalui simbol eksistensi manusia tidak akan teralienasi. Namun masih ada harapan bagi manusia modern, karena simbol yang telah didesakralisasikan itu masih dimilikinya, tersimpan dalam hati nuraninya atau dalam alam bawah sadarnya, dan itu dapat menjadi titik berangkat untuk pembaharuan dan kebangunan rohaninya.

Fungsi simbol yang mendasar ialah fungsi religius, yaitu mentransformasikan suatu hal atau suatu tindakan ke dalam sesuatu yang lain (yang kudus), yang tidak nampak pada pengalaman profan (duniawi). Simbol menyatakan yang kudus atau realitas kosmologis, menimbulkan solidaritas permanen antara manusia dengan yang kudus. Simbol bukanlah univokal (memiliki hanya satu macam ideologi atau kognitif), melainkan multivalen atau polivalen (menyatakan motivasi yang berbeda), sehingga simbol dapat menyingkapkan banyak arti pada saat yang sama. Banyaknya arti pada suatu simbol dapat pula menimbulkan kontradiksi, akan tetapi fungsi simbol juga adalah mempersatukan. Keadaan simbolsimbol yang kontradiksi selalu berada dalam sistem yang mempersatukan. Inilah fungsi penting simbol itu yaitu kapasitasnya mengekspresikan situasi paradoks dan juga mengekspresikan struktur realitas mendasar yang tidak dapat terekspresikan.

\section{Kesimpulan}

1. Hakikat kehidupan manusia yang religius ialah selalu haus akan keadaan yang paling dekat dengan Yang Kudus, Yang Transenden, atau Yang
Mutlak. Simbol dapat mengungkapkan aspek-aspek terdalam dari kenyataan yang tidak terjangkau oleh alat-alat pengenalan lain. Simbol seperti gambar (imago), mitos, dan ritual adalah sarana dan penunjuk untuk pengenalan dan peraihan pada keadaan yang paling dekat dengan Yang Kudus itu.

2. Seorang menjadi manusia yang sejati dan seutuhnya ialah dengan jalan menyesuaikan diri dengan ajaran simbol, yaitu meniru, mengimitasi, atau menjadi semakin serupa dan segambar dengan Yang Kudus.

3. Dunia manusia terdiri dari dua dimensi yaitu profan dan sakral. Masyarakat modern hidup dalam dunia profan yang berdimensi satu, yaitu suatu dunia yang didesakralisasi. Tetapi Eliade yakin bahwa pada manusia modern terus hidup suatu mitos dalam alam bawah sadarnya atau dalam hati nuraninya yang terdalam, yang merasuk keseluruhan pribadinya, dan mempunyai suatu kadar rohani lebih tinggi dari pada kehidupan alam sadarnya. Simbol-simbol tidak pernah menghilang dari konstelasi psikis yang aktual; simbol-simbol itu dapat berubah wajahnya, tetapi fungsinya tetap sama. Kita hanya cukup membuka baju barunya.

4. Dalam simbolisasi terjadi perpaduan dua gerak. Yang pertama ialah gerak imanen yaitu gerak dari manusia, atau gerak dari roh manusia yang senantiasa menyapa Yang Kudus melalui simbol. Yang kedua ialah gerak transenden yaitu gerak dari luar manusia, atau gerak dari Yang Kudus menyatakan diri-Nya melalui simbol. Dalam perpaduan dua gerak ini simbol berada di tengah-tengah antara manusia dan Yang Kudus, dan ber-fungsi sebagai ungkapan (dari hati nurani) dan jawaban (dari Yang Kudus). 
5. Simbol "berkaki dua". Satu kaki berakar dalam rasionalisasi atau konseptualisasi, dan kaki yang satunya lagi berakar dalam totalitas kehidupan manusia. Oleh karena itu simbol tidak mungkin ditafsir sampai tuntas karena sifatnya yang polivalen, multivokal, dan tidak univocal.

6. Dalam kehidupan berbangsa dan bernegara kita memiliki simbol yaitu Pancasila; sedangkan dalam kehidupan beragama kita memiliki simbol yaitu Wahyu atau Kitab Suci. Pancasila dan Kitab Suci sebagai simbol memberi dasar dinamika dan vitalitas dalam kehidupan berbangsa, bernegara, dan beragama; berfungsi sebagai ungkapan dan jawaban yang berdiri di tengah-tengah antara manusia Indonesia dengan Yang Kudus; tidak hanya mengundang untuk berpikir atau menjadi dasar berpikir tetapi juga mendorong dalam tindakan dan pengambilan keputusan; bahkan Pancasila dan Kitab Suci sebagai simbol bagi masyarakat Indonesia yang religius menuntut untuk diperlakukan sebagai partner dialog dalam membangun manusia Indonesia yang seutuhnya. Sebagai partner dialog yang selalu hadir di samping manusia Indonesia yang religius; ia mengajar, menyatakan kesalahan, memperbaiki kelakuan, dan mendidik dalam kebenaran.

\section{DAFTAR PUSTAKA}

Dibyasuharda. 1990. Dimensi Metafisik dalam Simbol. Universitas Gadjah Mada, Yogyakarta.

Saliba, John A. 1976. 'Homo Religiosus' in Mircea Eliade. E. J. Brill, Leiden.

Savickas, Alfonsas. 1980. The Concept of SYMBOL in the Psychology of C. G. Jung. Resch Verlack, Innsbruck.
Sutanto, Hasan. 2003. PBIK Jilid II: Konkordansi Perjanjian Baru. LAI, Jakarta.

Thayer, Joseph Henry. 1981. A GreekEnglish Lexicon of the New Testament. Zondervan Publishing House, Michigan.

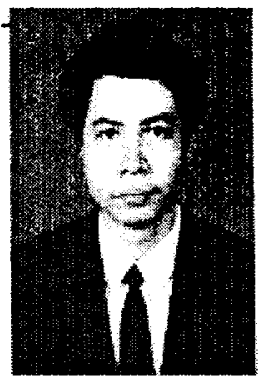

Pdt. Ivan Th. J. Weismann, M.Hum.

Alumni STTJ dan menyelesaikan Magister bidang Filsafat di Universitas Gajah Mada Yogyakarta. Melayani di GMII Makassar dan juga sebagai dosen part time STTJ bidang filsafat dan ilmu sosial 